\title{
$\bullet$ Micro-RNA 155 - On the Crosspoint of Inflammation and Carcinogenesis
}

IJCRR
Section: Healthcare
ISI Impact Factor
$(2019-20): 1.628$
IC Value (2019): 90.81
SJIF (2020) = 7.893
CC) (7) 9

\section{Antonia Atanassova ${ }^{1,3}$, Avgustina Georgieva1,2, Trifon Chervenkov4, Assia Konsoulova ${ }^{5,6}$}

'Gastroenterology Clinic, "St. Marina "University Hospital - Varna, Bulgaria; ${ }^{2}$ Second Internal Medicine Department, Medical University Varna, Bulgaria; ${ }^{3}$ Department of Anatomy and Cell Biology, Medical University - Varna, Bulgaria; ${ }^{4}$ Department of Medical Genetics, Medical University - Varna, Bulgaria; ${ }^{5}$ Complex Oncological Center - Burgas, Bulgaria; ${ }^{6}$ Women for Oncology - Bulgaria.

\section{ABSTRACT}

Background: As miR-155 influences a wide spectrum of inflammatory mediators, the study of this miRNA may suggest a new insight over the cancer development mechanisms. This is why the investigation of the miR-155 expression may reveal a potential relation between inflammation and gastrointestinal cancer.

The aim of the current study is to assess the miR-155 expression levels in patients with Crohn's disease (CD) and ulcerative colitis (UC).

Materials and Methods: The expression of miR-155 was studied in 70 consecutive patients with a confirmed diagnosis of IBD: 35 with CD and 35 with UC and 30 healthy controls. Disease activity was evaluated by the clinical symptoms, biochemical inflammatory parameters (CRP, FCP) and validated indices for evaluating IBD activity (CDAI for CD, Montreal Classification, and partial Mayo score for UC). 25(OH)D serum concentrations were measured by a commercial paramagnetic particle chemiluminescent immunoassay for the quantitative determination of total 25 -hydroxyvitamin $\mathrm{D}[25(\mathrm{OH})$ vitamin $\mathrm{D}]$ levels use on Access 2 Immunoassay Systems. Serum expression of miR-155 by reverse transcriptase, a real-time quantitative polymerase chain reaction (RT-qPCR), was tested in all.

Results: The analysis of the results showed that the circulating miR-155 was increased in Crohn-colitis (3.51 \pm 5.22$)$ and extensive UC (2.86 \pm 5.44$)$. Levels of CDAI above 150 were a risk factor for detection of increased miR-155 expression levels (OR=10, 91 (1.194-99,688); $p=0.017)$. An increased miR-155 expression was detected in patients, treated with corticosteroids $(5.20 \pm 8.91$ for UC and 3.39 \pm 3.10 for $C D)$. There was an inverse proportional moderate correlation with the levels of $F C P(r=-0.344: p<0.05)$. Vitamin D deficiency (25(OH)D) led to a 1.24 higher risk for increased serum level of miR-155.

Conclusions: The increased expression of miR-155 in patients with IBD is seen in disease localization in the colon, persistent inflammation, severe disease activity, vitamin D deficiency and treatment with corticosteroids.

Key Words: Fecal calprotectin, CRP, Crohn's disease, micro-RNA 155, Ulcerative colitis, Vitamin D

\section{INTRODUCTION}

Micro RNAs (miRNAs) are endogenous non-coding RNAs (ncRNAs), with length of about 22 nucleotides. The biogenesis of the miRNAs develops in several steps of post-transcriptional modifications in the nucleus and the cytoplasm. ${ }^{1}$ Over $60 \%$ of all genes, that code proteins, are regulated by miRNAs ${ }^{2,3,4}$ and one miRNA has on average 200 targets. ${ }^{5,6,7}$ miRNAs are important regulators of different cellular processes, including development, differentiation and signalization. ${ }^{8,9,10,11,12}$ The dysregulation of specific miRNAs may lead

\section{Corresponding Author:}

Assist. Prof. Avgustina Chavdarova Georgieva MD, PhD, Varna, 1 Hristo Smirnenski Bul., floor 11, Clinic of Gastroenterology, Multiprofile University Hospital for Active Treatment "Sveta Marina", city of Varna, Bulgaria; E-mail: avgustina_dobreva@yahoo.com

ISSN: 2231-2196 (Print)

ISSN: 0975-5241 (Online)

Received: 18.10 .2020

Revised: 03.12 .2020 to different diseases in humans: metabolic disturbances, cardiovascular or liver diseases as well as to immune dysfunction, including development of neoplasms. ${ }^{13,14,15}$

The expression of miRNA-155 (miR-155) is related to different cardiovascular diseases, inflammation and cancers. Its multifunctional regulatory role defines the interest towards this particular miRNA, that is considered to be the most extensively studied miRNA.

Expression of miR-155 was first reported in human spleen and thymus and subsequently in liver, lungs and kidneys. ${ }^{10,16}$ Later on, it was established that this miRNA has 
an abnormally increased expression in different activated immune cells ${ }^{17}$, which defines the important role of miR155 in immune response. ${ }^{18}$

miR-155 responds to many inflammatory stimuli as tumor necrosis factor alfa (TNF- $\alpha$ ), interleukin (IL) -1b, interferons, pathogen-associated molecular patterns (PAMP), damage-associated molecular patterns, (DAMP) ${ }^{19}$, alarmins (e.g. IL-1a $^{20}$, hypoxia ${ }^{21}$, as well as in Toll-like receptor ligans (TLR) in monocytes and macrophages $\mathrm{B}$ cells. ${ }^{22}$

The expression of miR-155 is controlled by multiple signal pathways. The regulatory cytokines, including Transforming Growth Factor beta (TGF- $\beta$ ) may induce or inhibit the expression of miR-155. ${ }^{23,24}$

In IBD, the negative feedback control over the inflammation is disturbed, leading to an excess activation of the inflammatory signal pathways. ${ }^{25,26}$

The endogeneous and the synthetic glucocorticoids are highly effective to slow down the process of acute inflammation via suppression of the miR-155 expression in the glucocorticoid receptor and/or via nuclear factor kappa-light-chainenhancer of activated B cells (NF-kB). 27,28,29

Chen Y, et.al, $2013^{30}$ identified that the vitamin D receptor signal pathway blocks the activation of NF-kB and thus leads to a decrease in miR-155 levels. As a result of this, the translation of SOCS1 is increased, allowing for an increase in the regulation of the negative feedback over the immune response. $^{31}$

At least $15-20 \%$ of all types of human cancer are related to chronic inflammation: diseases as IBD, colorectal cancer, colitis associated cancer (in ulcerative colitis), chronic gastritis and H. pylori (gastric cancer, GC). ${ }^{32}$ As miR-155 influences a wide spectrum of inflammatory mediators, the study of this micro-RNA may suggest a new insight over the cancer development mechanisms. This is why the investigation of the miR-155 expression may reveal a potential relation between inflammation and gastrointestinal cancer.

The aim of the current study is to assess the miR-155 expression levels in patients with Crohn's disease (CD) and ulcerative colitis (UC).

\section{MATERIALS AND METHODS}

The expression of miR-155 was studied in 70 consecutive patients with a confirmed diagnosis of IBD: 35 with $\mathrm{CD}$ and 35 with UC. Patients were treated at the Gastroenterology clinic during a period of one year (April 2019 - April 2020). 30 healthy individuals were also tested in order to define a healthy control study group. All IBD patients were classified according to the Montreal classification. The clinical course and treatment regiments were assessed. Disease activity was evaluated by the clinical symptoms, biochemical inflammatory parameters $(\mathrm{C}$ reactive protein - $\mathrm{CRP}$, fecal calprotectin - FCP) and validated indices for evaluating IBD activity (CDAI for CD, Montreal Classification, and partial Mayo score for UC). Biochemical parameters (CRP and FCP) were assessed as either normal or abnormal: FCP was considered as normal if levels were $<50 \mathrm{mg} / \mathrm{g}$; CRP was considered abnormal (elevated) if measured $>5 \mathrm{mg} / \mathrm{l} .25(\mathrm{OH})$ D serum concentrations were measured by a commercial paramagnetic particle chemiluminescent immunoassay for the quantitative determination of total 25-hydroxyvitamin D [25(OH) vitamin D] levels use on Access 2 Immunoassay Systems. Vitamin D deficiency was defined as a serum level of $25 \mathrm{OHD}$ lower than $50 \mathrm{nmol} / \mathrm{L}$; serum level above 50 $\mathrm{nmol} / \mathrm{L}$ but lower than $75 \mathrm{nmol} / \mathrm{L}$ was classified as vitamin D insufficiency.

Levels of miR-155 were assessed in blood serum. $5 \mathrm{ml}$ of blood was obtained via peripheral venous puncture with closed system BD Vacutainer ${ }^{\mathrm{TM}} \mathrm{SST}^{\mathrm{TM}}$ II Advance (Becton Dickinson, USA). After withdrawal, the blood sample was held 30 minutes at room temperature for clothing. Subsequently, it was centrifuged at $500 \times \mathrm{g}$ for 15 minutes at room temperature and the serum was separated and divided into aliquots of $500 \mu 1$ that were immediately stored at $-80^{\circ} \mathrm{C}$ until the moment of the analysis.

miRNAs were isolated from $200 \mu \mathrm{l}$ serum using a preexisting commercial miRNeasy Serum/Plasma Kit, catalogue №217184 (QIAGEN, Germany) as per protocol of the manufacturer.

3,5 $\mu 1$ control miRNA C. elegans miR-39: miRNeasy Serum/Plasma Spike-In Control, catalogue №219610 (QIAGEN, Germany), was added to each sample for normalization control; the samples were afterwards eluted in $14 \mu \mathrm{l}$ RNA-ase free water.

Each of the samples was subsequently submitted to reverse transcription via ready-to-use commercial kit miScript II RT Kit, catalogue №218161 (QIAGEN, Germany) as per manufacturer's protocol from $2,5 \mu 1$ eluted miRNA in a final volume of $10 \mu 1$ with HiFlex buffer and it was incubated at $37^{\circ} \mathrm{C}$ for 60 minutes and the enzyme was inactivated at 95 ${ }^{\circ} \mathrm{C}$ for 5 minutes.

Each of the samples was then submitted to quantitative real time polymerase chain reaction (rt-PCR) via a ready-to-use commercial kit miScript SYBR Green PCR Kit, catalogue № 218073 (QIAGEN, Germany) and prepared primers miScript Primer Assay, catalogue №218300 (QIAGEN, Germany) as per manufacturer's protocol: $1 \mu 1$ complementary DNA (cDNA) in $10 \mu 1$ reactions in 3 - times repetitions for 3 target miRNA in plates. The used miScript Primer Assay primers, catalogue № 218300 (QIAGEN, Germany) were as follows (the reference number is in the brackets): $\mathrm{Ce}_{-}$ 
miR-39 1 (MS00019789), Hs miR-155 2 (MS00031486), Hs_RNU6-2 11 (MS00033740). The used temperature parameters were as follows: maintenance for 15 minutes at 95 ${ }^{\circ} \mathrm{C}$ for enzyme activation; 40 cycles of 15 seconds at $94{ }^{\circ} \mathrm{C}$; 30 seconds at $70{ }^{\circ} \mathrm{C}$ with fluorescent reading; analysis of the melting curve in order to prove the specificity of the amplification: primary denaturation for 15 seconds at $95^{\circ} \mathrm{C}$ and cooling to $55^{\circ} \mathrm{C}$ for 60 seconds with an increase to $95^{\circ} \mathrm{C}$ with velocity of $+0,05^{\circ} \mathrm{C}$ per second and fluorescent reading. The analysis was done by QuantStudio Dx instrument of Applied Biosystems (USA) company; a threshold cycle (Ct) was assessed for each sample. Receiver Operating Characteristic Curve (ROC) was calculated to detect diagnostic performance of the test, sensitivity, specificity, positive and negative predictive values. Significance of the obtained results was judged at the $5 \%$ level.

The results were calculated with SPSS, v. 20.0 for Windows. We used variation, correlation, regression analyses as well risk assessment and comparative analyses ( $\chi 2$, t-test, ANOVA). $p<0.05$ was used as a level of significance.

The clinical trial was initiated after approval and permission №82 / 28.03.2019 of the Ethics commission for scientific research at the Medical University - Varna, Bulgaria.

Results: Table 1 shows the characteristics of the patients with $\mathrm{CD}, \mathrm{UC}$ and the healthy control subjects.

As there are no validated referent thresholds for the expression of any micro RNA, we calculated a cut-off threshold level in order to differentiate between healthy control subjects and patients with chronic inflammatory bowel diseases (IBD). This cut-off is specific for our cohort of studied healthy subjects and was used as a marker for assessment of the miR-155 expression in patients with $\mathrm{UC}$ and $\mathrm{CD}$. In our study, the cut-off value for the miR-155 is calculated at 1.37 (AUC $0.620 ; 0.497-0.742$ ) with a sensitivity of $61.4 \%$ and specificity of $63.3 \%$ (Fig. 1).

Table 2 shows the expression of miR-155 according to the characteristics of the patients with $\mathrm{CD}$ and $\mathrm{UC}$.

The analysis of the results of the miR-155 according to the localization of the disease indicates that the circulating miR155 was increased in Crohn-colitis (3.51 \pm 5.22$)$ and extensive $\mathrm{UC}(2.86 \pm 5.44)$. In patients with $\mathrm{CD}$, there was no significant difference in the miR-155 expression levels in inflammatory (B1) or stenotic (B2) form of the disease, whereas in patients with UC, not achieving a significant remission (chronic persistent form), the expression of miR-155 was significantly higher as compared to patients with chronic relapsing course of disease (5.53 \pm 9.56 vs $1.54 \pm 1.22 ; \mathrm{P}=0.032)$.

The correlation analysis showed a proportional moderate correlation between miR-155 expression CDAI ( $\mathrm{r}=0.415$; $\mathrm{p}=0.015$ ). This indicates that the progression of the disease activity led to an increase in the serum expression levels of miR-155. Patients with moderate CD activity had significantly increased expression of miR-155 as compared to patients in remission or with mild activity $(6.08 \pm 5.12$ vs $2.11 \pm 2.09$ and $2.11 \pm 1.07 ; p=0.009)$. Levels of CDAI above 150 were a risk factor for detection of increased miR-155 expression levels (OR=10,91 (1.194-99,688); $\mathrm{p}=0.017)$.

The analysis of the correlation between the severity of the $\mathrm{UC}$ and the expression of miR- 155 showed that the severity index S (as per the Montreal classification) had a proportional moderate correlation with the increased expression of miR-155 ( $\mathrm{r}=0.321 ; \mathrm{p}=0.048)$. Patients with severe disease activity had a significantly higher expression levels of miR-155 ( $\mathrm{p}<0.05)$. On the other hand, the endoscopic activity, measured by the Partial Mayo score, did not show a correlation with the miR-155 expression - the miR-155 levels were increased in patients with moderate disease activity $(4.82 \pm 9.05)$ and decreased in patients with severe activity (2.23 \pm 1.75$)$. In patients with UC in remission or with mild disease activity, the miR-155 expression levels were close or just mildly below the threshold cut- off value, defined for the healthy control subjects.

Regarding the treatment, an increased miR-155 expression was detected in patients, treated with corticosteroids (5.20 \pm 8.91 for UC and $3.39 \pm 3.10$ for $\mathrm{CD}$ ). The expression of miR-155 was similar in patients, treated with immune modulators in both $\mathrm{CD}$ and UC. In patients with UC, receiving biological treatment, the levels of serum miR-155 expression are below the defined cut-off value for healthy controls.

Other widely used biomarkers, used to biochemically assess inflammation in patients with IBD, are CRP and FCP. The mean level of CRP levels in patients with IBD was $19.31 \mathrm{mg} / 1 \pm 32.69 \mathrm{mg} / 1(0.09-160.0 \mathrm{mg} / \mathrm{l})$, and for FCP it was $459.19 \mathrm{mg} / \mathrm{g} \pm 490.74 \mathrm{mg} / \mathrm{g}(2.00-1800 \mathrm{mg} / \mathrm{g})$. The results of the analysis of the correlation between the miR155 expression and CRP or FCP showed that the levels of the tested miR do not correlate with the levels of CRP, but there was an inverse proportional moderate correlation with the levels of FCP $(r=-0.344: p<0.05)$.

The mean 25(OH)D serum expression level in patients with IBD was $44.14 \mathrm{nmol} / \mathrm{L} \pm 17.47 \mathrm{nmol} / \mathrm{L}$ with a variation between $2.76 \mathrm{nmol} / \mathrm{L}$ and $90.65 \mathrm{nmol} / \mathrm{L}$. These results showed that the expression of miR-155 was different according to the serum levels of $25(\mathrm{OH}) \mathrm{D}$. In patients with $25(\mathrm{OH}) \mathrm{D}$ serum levels $<50 \mathrm{nmol} / \mathrm{L}$, the expression of miR-155 was significantly higher as compared to patients with $25(\mathrm{OH}) \mathrm{D}$ levels $\geq 50 \mathrm{nmol} / \mathrm{L}(3.53 \pm 6.35$ vs $2.38 \pm 2.23$; $\mathrm{p}=0.041)$. Vitamin D deficiency $(25(\mathrm{OH}) \mathrm{D})$ led to a 1.24 higher risk for increased serum level of miR-155. 


\section{DISCUSSION}

Many studies show that the miR-155 expression is increased in patients with IBD, both in UC and CD..$^{33,34,35}$ Our results also correspond with previous publications, showing a significantly higher miR-155 expression levels in patients with IBD as compared to healthy individuals.

The expression of miR-155 in patients with active UC is increased in comparison to healthy individuals. This is a result of the direct decrease in the expression of FOXO3a gene which may additionally activate the NF- $\kappa B$ signaling pathway and increase the inflammatory cytokines and thus maintain inflammation. ${ }^{36}$ These results are confirmed by our study as well.

In our trial, patients with persistent inflammation and no remission as well as a localization of their disease in the colon, have a significantly higher miR-155 expression. It is well known that chronic inflammation is the background of the IBD, UC-associated carcinoma as well of colorectal cancer. ${ }^{32}$

Logically, the change in the expression of miR-155 levels during monitoring of inflammatory processes in IBD could be a potential biomarker for early discovery of dysplasia. Further larger prospective cohort trials in IBD patients are needed to explore the role of miR-155 in the tumorigenesis and to validate the change in its expression levels as a potential biomarker for occurrence of dysplasia and its transition into tumorigenesis.

There are publications that the localization and the disease course may be related to different miR-155 levels. Increased miR-155 levels in intestinal myofibroblasts and in mucosa of the colon are related to the control of the Th17 inflammatory pathway, targeting FOXO3a and IL-8, thus promoting fibrosis formation. ${ }^{37,38}$

It has been proven that miR-155 plays a significant role in the control of the inflammation and the immune regulation and it is logical that its expression is significantly higher in patients with active disease, regardless of the method, assessing the activity of the disease.

Chen Y. et.al. describes a new mechanism, where vitamin $\mathrm{D}$ receptor signaling pathway controls the TLR4-mediated inflammation in IBD and the immune mediated diseases. This anti- inflammatory mechanism is mediated via miR155 suppressing the regulation, decreasing SOCS1. This leads to enhancement of the regulation of the negative feedback. Vitamin D - receptor signaling pathway inhibits miR-155 via a transcription mechanism..$^{30}$ This process of suppression of the miR-155 expression is also confirmed in our study where we established an inverse proportional correlation between the vitamin D levels and the miR-155 expression. Vitamin D deficiency correlates with higher miR-155 expression levels.
Treatment with 5-ASA (5 - aminosalicylic acid) and biologicals is highly effective in patients with UC and leads to a decrease in the miR-155 expression to levels, close to or below the threshold cut-off values as in health individuals. On the other hand, in patients with CD, treated with 5-ASA, the levels of miR-155 do not decrease to such extent which shows the persistence of the inflammation and explains the difficult achievement of remission in patients with $\mathrm{CD}$.

Treatment with corticosteroids is highly effective to suppress the acute inflammation via a change in the miR-155 expression..$^{27,28}$ In our cohort of patients, treated with corticosteroids in order to induce remission, the levels of miR-155 are increased and this may be explained by the fact that the disease remission, induced by corticosteroids is short-term and unstable as there is a high risk of recurrence or complications of the disease.

\section{CONCLUSION}

The increased expression of miR-155 in patients with IBD is seen in disease localization in the colon, persistent inflammation, severe disease activity, vitamin D deficiency and treatment with corticosteroids. Decreased miR-155 expression with levels, close to the levels of healthy subjects is reported predominantly in patients with UC in remission, induced by biological therapy. As miR-155 has a significant role in the assessment of the inflammatory process and plays an important role in the tumorigenesis, a longer monitoring of the dynamics of its expression in patients with active IBD may reveal a potential crosspoint between inflammation and gastrointestinal cancer.

\section{ACKNOWLEDGEMENT}

Authors acknowledge the immense help received from the scholars whose articles are cited and included in references of this manuscript. We are also grateful to authors/ editors/publishers of all those articles, journals and books from where the literature of this article has been reviewed and discussed.

\section{Authors' Contribution:}

Antonia Atanassova- conceived and designed the study, performed the statistical analysis, analyzed the data and drafted the manuscript

Trifon Chervenkov- performed the miRNA expression profiles in blood

Avgustina Georgieva- collected data and drafted the manuscript

Assia Konsoulova- critical revision of manuscript 
All authors critically revised the manuscript, approved the final version to be published, and agree to be accountable for all aspects of the work.

Source of Funding: This studies as no fund from any authorities

\section{Conflict of Interest: None to declare}

\section{REFERENCES}

1. Denli AM, Tops BB, Plasterk RH, Ketting RF, Hannon GJ. Processing of primary microRNAs by the Microprocessor complex. Nature. 2004 Nov 11;432(7014):231-235.

2. Bartel DP. MicroRNAs: genomics, biogenesis, mechanism, and function. Cell. 2004 Jan 23;116(2):281-297.

3. Croce CM. Causes and consequences of microRNA dysregulation in cancer. Nat Rev Genet. 2009 Oct;10(10):704-714.

4. Lin PY, Yu SL, Yang PC. MicroRNA in lung cancer. Br JCancer 2010; 103(8):1144-1148.

5. Bagga S, Bracht J, Hunter S, Massirer K, Holtz J, Eachus R,et al. Regulation by let-7 and lin-4 miRNAsresults in target mRNA degradation. Cell 2005; 122(4):553-563.

6. Krek A, Grun D, Poy MN, Wolf R, Rosenberg L, Epstein EJ, et al. Combinatorial microRNA target predictions. Nat Genet 2005; 37(5):495-500.

7. John B, Sander C, Marks DS. Prediction of human microRNA targets. Methods Mol Biol 2006;342:101-113.

8. Ambros V. The functions of animal microRNAs. Nature 2004; 431(7006):350-355.

9. Bagga $\mathrm{S}$, Pasquinelli AE. Identification and analysis of microRNAs. Genet Eng (N Y), 2006; 27:1-20.

10. Hwang HW, Mendell JT. MicroRNAs in cell proliferation, cell death, and tumorigenesis. Br J Cancer 2006; 94(6):776-780.

11. Du T, Zamore PD. Beginning to understand microRNA function. Cell Res 2007; 17(8):661-663.

12. Rane S, Sayed D, Abdellatif M: MicroRNA with a MacroFunction. Cell Cycle 2007; 6 (15):1850-1855.

13. Poy MN, Spranger M, Stoffel M. microRNAs and the regulation of glucose and lipid metabolism. Diabetes Obes Metab 2007; 9 Suppl 2:67-73.

14. Blenkiron C, Miska EA. miRNAs in cancer: approaches, aetiology, diagnostics and therapy. Hum Mol Genet 16 Spec No 2007; 1:R106-R113.

15. Van Rooij E, Olson EN. MicroRNAs: powerful new regulators of heart disease and provocative therapeutic targets. J Clin Invest 2007; 117(9):2369-2376.

16. Tam W. Identification and characterization of human BIC, a gene on chromosome 21 that encodes a noncoding RNA. Gene 2001; 274(1-2):157-167.

17. Landgraf P, Rusu M, Sheridan R, Sewer A, Iovino N, Aravin A, et al. A mammalian microRNAexpression atlas based on small RNA library sequencing. Cell 2007; 129(7):1401-1414.

18. Costinean S, Zanesi N, Pekarsky Y, Tili E, Volinia S, HeeremaN, Croce CM. Pre-B cell proliferation and lympho-blastic leuke$\mathrm{mia} /$ high-grade lymphoma in $\mathrm{E}(\mathrm{mu})-\mathrm{miR} 155$ transgenic mice. Proc Natl Acad Sci U S A 2006; 103(18):7024-7029.

19. O'Connell RM, Taganov KD, Boldin MP, Cheng G, BaltimoreD. MicroRNA-155 is induced during the macrophageinflammatory response. Proc Natl Acad Sci U S A 2007; 104(5):1604-1609.

20. Kurowska-Stolarska M, Hasoo MK, Welsh DJ, Stewart L,McIntyre D, Morton BE, et al. The role of microRNA-155/ liver X receptor pathway inexperimental and idiopathic pulmonary fibrosis. J AllergyClin Immunol 2017; 139(6):1946-1956.

21. Bruning U, Cerone L, Neufeld Z, Fitzpatrick SF, Cheong A,Scholz CC, et al. MicroRNA-155 promotesresolution of hypoxia-inducible factor 1alpha activity duringprolonged hypoxia. Mol Cell Biol 2011; 31(19):4087-4096.

22. Mashima R. Physiological roles of miR-155. Im-munology 2015; 145(3):323-333.

23. Pottier N, Maurin T, Chevalier B, Puissegur MP, Lebrigand K, Robbe-Sermesant K, et al. Identification of keratinocyte growthfactor as a target of microRNA-155 in lung fibroblasts: im- plication in epithelial-mesenchymal interactions. PLoS One 2009; 4(8):e6718.

24. Valeri N, Gasparini P, Fabbri M, Braconi C, Veronese A, LovatF, et al. Modulation of mismatch repairand genomic stability by miR-155. Proc Natl Acad Sci U S A 2010; 107(15):6982-6987.

25. Yoshimura A, Naka T, Kubo M. SOCS proteins, cytokine signaling and immune regulation. Nature Reviews Immunology 2007; 7, 454-465.

26. Alhassan Mohammed H, Mirshafiey A, Vahedi H, Hemmasi G, Moussavi Nasl Khameneh A, Parastouei K, et al. Immunoregulation of Inflammatory and Inhibitory Cytokines by Vitamin D3 in Patients with Inflammatory Bowel Diseases. Scand J Immunol. 2017 Jun;85(6):386-394.

27. Zheng Y, Xiong S, Jiang P, Liu R, Liu X, Qian J, et al. Glucocorticoids inhibit lipopolysaccharide- mediatedinflammatory response by downregulating microRNA-155: anovel anti-inflammation mechanism. Free Radic Biol Med 2012; 52(8):1307-1317.

28. Chinenov Y, Coppo M, Gupte R, Sacta MA, Rogatsky I. Glucocorticoid receptor coordinates transcription factor-dominated regulatory network in macrophages. BMC Geno-mics 2014; 15:656.

29. Brown CY, Dayan S, Wong SW, Kaczmarek A, Hope CM, Pederson SM, et al. FOXP3 and miR-155 cooperate to controlthe invasive potential of human breast cancer cells by downregulating ZEB2 independently of ZEB1. Oncotarget 2018; 9 (45):27708-27727.

30. Chen Y, Liu W, Sun T, Huang Y, Wang Y, Deb DK, et al. 1,25-Dihydroxyvitamin D promotes negative feedback regulation of TLR signaling via targeting microRNA-155-SOCS1 in macrophages. J Immunol. 2013 Apr 1;190(7):3687-3695.

31. Hart PH, Gorman S, Finlay-Jones JJ. Modulation of the immune system by UV radiation: more than just the effects of vitamin D? Nature Reviews Immunology 2011; 11, 584-596.

32. Rath T, Billmeier U, Waldner M.J, Atreya R, Neurath MF. From physiology to disease and targetedtherapy: Interleukin-6 in inflammation and inflammation-associated carcinogenesis. Arch. Toxicol. 2015; 89,541-554.

33. Fasseu M, Tréton X, Guichard C, Pedruzzi E, Cazals-Hatem D, Richard C, et al. Identification of restricted subsets of mature microRNA abnormally expressed in inactive colonic mucosa of patients with inflammatory bowel disease. PLoS One. 2010 Oct 5;5(10):e13160.

34. Takagi T, Naito Y, Mizushima K, Hirata I, Yagi N, Tomatsuri N, et al. Increased expression of microRNA in the inflamed colonic mucosa of patients with active ulcerative colitis.J. Gastroenterol. Hepatol. 2010; 25, S129-S133.

35. Wu F, Zhang S, Dassopoulos T, Harris ML, Bayless TM, Meltzer SJ, et al. Identification of microRNAs associated with ileal and colonic Crohn's disease. Inflamm Bowel Dis. 2010 Oct;16(10):1729-38.

36. Kaser A, Zeissig S. Blumberg, R.S. Inflammatory bowel disease.Annu. Rev. Immunol. 2010; 28, 573-621. 
37. Min M, Peng L, Yang Y, Guo M, Wang W,Sun G. MicroRNA-155 is involved in the pathogenesis of ulcerative colitis by targeting FOXO3a. Inflamm Bowel Dis 2014; 20(4):652-9.
38. Pathak S, Grillo AR, Scarpa M, Brun P, D’Incà R, Nai L, et al. MiR-155 modulates the inflammatory phenotype of intestinal myofibroblasts by targeting SOCS1 in ulcerative colitis. Exp Mol Med 2015; 47: e164. doi: 10.1038/emm.2015.21.

Table 1: Characteristics of the patients with IBD according to the Montreal classification

\begin{tabular}{|c|c|c|c|c|c|c|}
\hline Index & & $\begin{array}{l}\text { Active CD } \\
\qquad(\mathbf{n}=\mathbf{2 0})\end{array}$ & $\begin{array}{c}C D \text { in } \\
\text { remission } \\
(n=15)\end{array}$ & $\begin{array}{c}\text { Active UC } \\
(\mathbf{n}=\mathbf{2 0})\end{array}$ & $\begin{array}{c}\mathrm{UC} \text { in } \\
\text { remission } \\
(\mathrm{n}=15)\end{array}$ & $\begin{array}{l}\text { Healthy } \\
\text { controls } \\
(n=30)\end{array}$ \\
\hline \multirow{2}{*}{$\begin{array}{l}\text { Age, years } \\
\text { (mean } \pm S D \text {, } \\
\text { range) }\end{array}$} & Current & $\begin{array}{c}41.1 \pm 12.9 \\
(18-71)\end{array}$ & $\begin{array}{c}42.1 \pm 14.8 \\
(23-75)\end{array}$ & $\begin{array}{c}37.9 \pm 13.8 \\
(19-73)\end{array}$ & $\begin{array}{c}46.4 \pm 16.1 \\
(18-71)\end{array}$ & $\begin{array}{c}26.2 \pm 6.2 \\
(18-42)\end{array}$ \\
\hline & Diagnosis & $\begin{array}{c}35 \cdot 5 \pm 11.6 \\
(14-56)\end{array}$ & $\begin{array}{c}36.8 \pm 15.1 \\
(19-75)\end{array}$ & $\begin{array}{c}30.8 \pm 11.5 \\
(15-53)\end{array}$ & $\begin{array}{c}35 \cdot 3 \pm 14 \cdot 3 \\
(17-62)\end{array}$ & - \\
\hline \multirow[t]{2}{*}{ Sex } & Male & $13 / 65.0 \%$ & $5 / 33 \cdot 3 \%$ & $7 / 35.0 \%$ & $8 / 53 \cdot 3 \%$ & $15 / 50.0 \%$ \\
\hline & Female & $7 / 35.0 \%$ & $10 / 66.7 \%$ & $13 / 65.0 \%$ & $7 / 46.7 \%$ & $15 / 50.0 \%$ \\
\hline \multirow{3}{*}{$\begin{array}{l}\text { Localization } \\
\text { of } \mathrm{CD} / \mathrm{UC}\end{array}$} & $\mathrm{L} 1 / \mathrm{E}_{1}$ & $13 / 65.0 \%$ & $6 / 40.0 \%$ & - & $1 / 6,7 \%$ & - \\
\hline & $\mathrm{L}_{2} / \mathrm{E}_{2}$ & - & $5 / 33 \cdot 3 \%$ & $8 / 40.0 \%$ & $3 / 20.0 \%$ & - \\
\hline & $\mathrm{L}_{3} / \mathrm{E}_{3}$ & $7 / 35.0 \%$ & $4 / 26.7 \%$ & $12 / 60.0 \%$ & $11 / 73.3 \%$ & - \\
\hline \multirow[t]{6}{*}{ Behavior } & $\mathrm{B} 1$ & $5 / 25.0 \%$ & $12 / 80.0 \%$ & - & - & - \\
\hline & $\mathrm{B} 2$ & $9 / 45.0 \%$ & $2 / 13 \cdot 3 \%$ & - & - & - \\
\hline & $\mathrm{B}_{3}$ & $5 / 25.0 \%$ & $1 / 6.7 \%$ & - & - & - \\
\hline & $\mathrm{B}_{2}-\mathrm{B}_{3}$ & $1 / 5.0 \%$ & - & - & - & - \\
\hline & Chronic relapsing & - & - & $13 / 65.0 \%$ & $15 / 100 \%$ & - \\
\hline & $\begin{array}{l}\text { Chronic } \\
\text { persistent }\end{array}$ & - & - & $7 / 35.0 \%$ & - & - \\
\hline $\begin{array}{l}\text { Duration of } \\
\text { the IBD, } \\
\text { months }\end{array}$ & $\begin{array}{l}(\text { mean } \pm S D, \\
\text { range })\end{array}$ & $67.4 \pm 66.4(3-204)$ & $66.3 \pm 51.6(3-156)$ & $\begin{array}{c}84.7 \pm 97 \cdot 3(1- \\
336)\end{array}$ & $\begin{array}{c}150.8 \pm 137.6(12- \\
492)\end{array}$ & - \\
\hline \multirow[t]{4}{*}{ Treatment } & $5 \mathrm{ASA}$ & $1 / 5.0 \%$ & $1 / 6.7 \%$ & $7 / 35.0 \%$ & - & - \\
\hline & Corticosterioids & $6 / 30.0 \%$ & $1 / 6.7 \%$ & $8 / 40.0 \%$ & $5 / 33.3 \%$ & - \\
\hline & $\begin{array}{l}\text { Immune } \\
\text { modulators }\end{array}$ & $1 / 5.0 \%$ & $1 / 6.7 \%$ & $2 / 10.0 \%$ & $9 / 60.0 \%$ & - \\
\hline & $\begin{array}{l}\text { Biological } \\
\text { treatment }\end{array}$ & $12 / 60.0 \%$ & $12 / 80.0 \%$ & $3 / 15.0 \%$ & $1 / 6.7 \%$ & - \\
\hline \multirow[t]{3}{*}{$\begin{array}{l}\text { Vitamin D } \\
(25 \mathrm{OH} \mathrm{D})\end{array}$} & $\begin{array}{l}\text { (mean } \pm S D, \\
\text { range) }\end{array}$ & $\begin{array}{l}39.45 \pm 15.65 \\
(2.76-71.14)\end{array}$ & $\begin{array}{l}53.02 \pm 16.77 \\
(26.37-73.17)\end{array}$ & $\begin{array}{c}40.32 \pm 15.41 \\
(25.66-77.0)\end{array}$ & $\begin{array}{c}55.22 \pm 21.07 \\
(26.41-90.65)\end{array}$ & - \\
\hline & $<50 \mathrm{nmol} / \mathrm{L}$ & $15 / 75.0 \%$ & $2 / 28.6 \%$ & $11 / 73 \cdot 3 \%$ & $3 / 37 \cdot 5 \%$ & - \\
\hline & $>50 \mathrm{nmol} / \mathrm{L}$ & $5 / 25.0 \%$ & $5 / 71.4 \%$ & $4 / 26.7 \%$ & $5 / 62.5 \%$ & - \\
\hline \multirow[t]{3}{*}{ CRP (mg/l) } & $\begin{array}{l}\text { (mean } \pm \mathrm{SD}, \\
\text { range) }\end{array}$ & $\begin{array}{l}39.22 \pm 45.17 \\
(0.17-160.0)\end{array}$ & $\begin{array}{c}3.24 \pm 2.51 \\
(0.09 \pm 8.34)\end{array}$ & $\begin{array}{c}22.51 \pm 29.85 \\
\left(0.47^{-91.9)}\right.\end{array}$ & $\begin{array}{l}2.30 \pm 2.07 \\
(0.13-6.90)\end{array}$ & - \\
\hline & $<5 \mathrm{mg} / \mathrm{L}$ & $5 / 25.0 \%$ & $11 / 73 \cdot 3 \%$ & $6 / 30.0 \%$ & $10 / 76.9 \%$ & - \\
\hline & $>5 \mathrm{mg} / \mathrm{L}$ & $15 / 75.0 \%$ & $4 / 26.7 \%$ & 14/70.0\% & $3 / 23.1 \%$ & - \\
\hline \multirow[t]{3}{*}{$\mathrm{FCP}(\mathrm{mg} / \mathrm{g})$} & $\begin{array}{l}\text { (mean } \pm S D, \\
\text { range) }\end{array}$ & $\begin{array}{c}449.14 \pm 339.82 \\
(110.0-910.0)\end{array}$ & $\begin{array}{c}112.91 \pm 194.48 \\
(2.0-648.0)\end{array}$ & $\begin{array}{c}1054.89 \pm 413.67 \\
(300.0-1800.0)\end{array}$ & $\begin{array}{c}198.07 \pm 268.7 \\
(12.5-759.0)\end{array}$ & - \\
\hline & $<50 \mathrm{mg} / \mathrm{g}$ & $7 / 100 \%$ & $6 / 60.0 \%$ & - & $4 / 57.1 \%$ & - \\
\hline & $>50 \mathrm{mg} / \mathrm{g}$ & - & $4 / 40.0 \%$ & 9/100.0 \% & $3 / 42.9 \%$ & - \\
\hline
\end{tabular}


Table 2: Expression of micro-RNA 155 according to the main characteristics of the patients with CD and UC.

\begin{tabular}{|c|c|c|c|}
\hline \multirow[t]{2}{*}{ Baseline characteristics } & & \multicolumn{2}{|c|}{ miR-155 expression (mean \pm SD) } \\
\hline & & $\mathrm{CD}(\mathbf{n}=35)$ & UC $(n=35)$ \\
\hline \multirow[t]{2}{*}{ Location } & $\mathrm{L} 1 / \mathrm{E}_{1}$ & $2.51 \pm 2.42$ & 2.19 \\
\hline & $\mathrm{L} 2 / \mathrm{E}_{2}$ & $3 \cdot 51 \pm 5.22$ & $1.25 \pm 0.96$ \\
\hline $\mathrm{CD} / \mathrm{UC}$ & $\mathrm{L}_{3} / \mathrm{E}_{3}$ & $2.53 \pm 1.84$ & $2.86 \pm 5.44$ \\
\hline \multirow[t]{2}{*}{ Behavior } & $\mathrm{B}_{1}$ & $2.87 \pm 3 \cdot 36$ & - \\
\hline & $\mathrm{B}_{2}$ & $2.89 \pm 2.55$ & - \\
\hline \multirow{4}{*}{$\mathrm{P}=0.032$} & $\mathrm{~B}_{3}$ & $1.86 \pm 1.06$ & - \\
\hline & $\mathrm{B}_{2}-\mathrm{B}_{3}$ & 1.48 & - \\
\hline & chronic recurrent & - & $1.54 \pm 1.22$ \\
\hline & chronic persistent & - & $5 \cdot 53 \pm 9 \cdot 56$ \\
\hline \multirow[t]{2}{*}{ CDAI } & Remission & $2.11 \pm 2.09$ & - \\
\hline & Mild & $2.11 \pm 1.07$ & - \\
\hline$P=0.009$ & Moderate & $6.08 \pm 5.12$ & - \\
\hline \multirow[t]{4}{*}{ S (severity) } & Remission & - & $1.11 \pm 0.75$ \\
\hline & Mild & - & $1.33 \pm 1.02$ \\
\hline & Moderate & - & $1.63 \pm 0.48$ \\
\hline & Severe & - & $4.92 \pm 7.93$ \\
\hline \multirow[t]{4}{*}{ Mayo score } & Remission & - & $1.22 \pm 0.79$ \\
\hline & Mild & - & $1.34 \pm 0.85$ \\
\hline & Moderate & - & $4.82 \pm 9.05$ \\
\hline & Severe & - & $2.23 \pm 1.75$ \\
\hline \multirow[t]{4}{*}{ Treatment } & 5ASA & $2.71 \pm 2.76$ & $1.65 \pm 1.51$ \\
\hline & Corticosteroids & $3 \cdot 39 \pm 3.10$ & $5.20 \pm 8.91$ \\
\hline & Immune modulators & $1.94 \pm 0.72$ & $1.90 \pm 1.26$ \\
\hline & Biological treatment & $2.51 \pm 2.85$ & $1.23 \pm 0.86$ \\
\hline \multirow[t]{2}{*}{ Vitamin D (25 OH D) } & $<50 \mathrm{nmol} / \mathrm{L}$ & $3.15 \pm 2.69$ & $1.44 \pm 0.95$ \\
\hline & $>50 \mathrm{nmol} / \mathrm{L}$ & $2.80 \pm 3.73$ & $4 \cdot 34 \pm 8.58$ \\
\hline \multirow[t]{2}{*}{ CRP (mg/l) } & $<5 \mathrm{mg} / \mathrm{L}$ & $3.05 \pm 3.37$ & $1.11 \pm 0.89$ \\
\hline & $>5 \mathrm{mg} / \mathrm{L}$ & $2.34 \pm 2.16$ & $3.63 \pm 6.18$ \\
\hline \multirow[t]{2}{*}{ FCP (mg/g) } & $<50 \mathrm{mg} / \mathrm{g}$ & $4.04 \pm 3.98$ & $1.63 \pm 0.70$ \\
\hline & $>50 \mathrm{mg} / \mathrm{g}$ & $1.45 \pm 0.57$ & $3.89 \pm 7.44$ \\
\hline
\end{tabular}

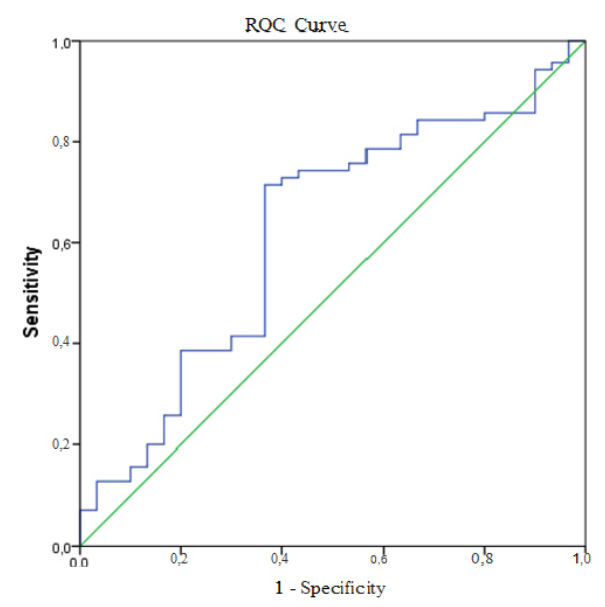

Figure 1: A receiver operating characteristic curve (ROC curve) for serum miR-155 expression to predict cases (from control). 